\title{
ANALISIS FAKTOR-FAKTOR YANG MEMPENGARUHI PENDAPATAN NELAYAN TANGKAP PANCING RAWAI KELURAHAN SUMPANG BINANGAE KACAMATAN BARRU
}

\author{
ANALYSIS OF FACTORS THAT INFLUENCE FISHERMAN INCOME FISHING \\ CAPACITY OF SUMPANG BINANGAE DISTRICT, BARRU DISTRICT
}

\author{
Abdul Hafid ${ }^{1}$, Ilham Abu ${ }^{2}$ \\ ${ }^{1}$ Manajemen, Universitas Indonesia Timur \\ (abdulhafidasad@gmail.com) \\ ${ }^{2}$ Pendidikan Ekonomi, Universitas Mulawarman \\ (ilhamkopma@gmail.com)
}

\begin{abstract}
ABSTRAK
Pekerjaan sebagai nelayan merupakan pekerjaan yang memiliki tingkat resiko yang cukup tinggi. Selain itu, pendapatan yang diterima dari hasil tangkapan ikan tidak sepenuhnya mampu memenuhi kebutuhan ekonomini keluargannya. Adanya banyak factor yang bisa menyebabkan pendapatan nelayan seperti factor modal, alat tangkap, lama melaut dan factor lainnya. Tujuan penelitian ini adalah untuk menganalisis faktor-faktor yang mempengaruhi pendapatan nelayan tangkap pancing Rawai di Kelurahan Sumpang Binagae di Kecamatan Barru. Metode yang digunakan dalam penelitian ini adalah deskritif kuantitatif. Populasi dalam penelitian ini sebanyak 46 kepala keluarga nelayan di Kelurahan Sumpang Binangae. Teknik pengumpulan data melalui observasi, dokumentasi, wawancara dan kuesioner sedangkan Teknik analisis data yang digunakan adalah analisis regeresi berganda. Hasil penelitian menunjukkan bahwa besar-kecilnya pendapatan nelayan yang menggunakan alat tangkap pancing secara nyata dan signifikan dipengaruhi oleh variabel modal kerja, alat tangkap pancing, lama melaut dan pengalaman sedangkan variabel tanggungan keluarga, pendidikan dan umur tidak berpengaruh nyata secara signifikan terhadap pendapatan nelayan. pendapatan nelayan tangkap pancing rawai memiliki tingkat pendapatan yang cukup baik disebabkan jenis tangkapan ikannya memiliki nilai ekonomis atau harga jual yang lebih tinggi.
\end{abstract}

Kata Kunci: Pendapatan, Nelayan, Alat Tangkap.

\section{ABSTRACT}

Working as a fisherman is a job that has a fairly high level of risk. In addition, the income received from fish catches is not fully able to meet the economic needs of his family. There are many factors that can cause fishermen income such as capital, fishing gear, fishing time and other factors. The purpose of this study was to analyze the factors that influence the income of Rawai fishing in the Sumpang Binagae Village in Barru regency. The method used in this research is quantitative descriptive. The population in this study were 46 family heads of fishermen in Sumpang Binangae Village. Data collection techniques through observation, documentation, interviews and questionnaires while the data analysis technique used is multiple regression analysis. The results showed that the size of the income of fishermen who use fishing gear significantly and significantly influenced by the variable working capital, fishing gear, length of sea fishing and experience while the dependent variables of family, education and age did not significantly influence the income of fishermen. Income for longline fishing has a good income level due to the type of fish catches that have economic value or higher selling prices.

Keywords: Income, Fishermen, Fishing Equipment. 


\section{PENDAHULUAN}

Indonesia merupakan salah satu negara kepualaun terbesar di dunia yang terdiri dari 17.508 pulau dengan garis pantai $81.000 \mathrm{~km}$ dan luas laut sekitar 3,1 juta $\mathrm{km}^{2}$ yang tentunya memiliki potensi yang sangat besar baik potensi sumber daya hayani manupun non hayati. Hal ini berdampak pada masyarakat yang menenpati wilayah daerah pesisir banyak yang menggantungkan atau mencari nafkah dalam memenuhi kebutuhan hidupnya melalui kekayaan laut yang sangat melimpah tesebut.

Kabupaten Barru merupakan daerah yang mempunyai luas wilayah 1174,72 $\mathrm{Km}^{2}$, dimana memiliki potensi perikanan laut yang cukup besar, karena memiliki garis pantai yang mencapai $78 \mathrm{Km}$. Sektor kelautan Kabupaten Barru berbatasan dengan selat makassar di sebelah barat yang tentunya dengan potensi yang dimiliki ini bisa dimanfaatkan untuk meningkatkan pendapatan daerah, penyerapan tenaga kerja yang pada akhirnya akan meningkatkan kesejahteraan rakyat.

Nelayan di Kelurahan Sumpang Binangae di Kecamatan Barru merupakan salah satu daerah dimana sebagian warganya berprofesi sebagai nelayan terutama nelayan yang dalam aktivitas melautnya (menangkap ikan) hanya menggunakan hanya menggunakan alat tangkap pancing.

Nelayan tangkap yang menggunakan alat pancing rawai di Kelurahan Sumpang Binangae dari segi aspek pendapatan masih merasa kurang atau tidak sesuai apa yang di harapkan bila dibandingkan dengan waktu, tenaga dan biaya yang dikelurarkan dalam memperoleh pendapatan. Selain itu, resiko yang harus dihadapi oleh para nelayan pada saat melaut yang cukup besar seperti resiko faktor alam.

Pendapatan seorang nelayan tidaklah menentu terkadang mendapatkan pendapatan yang cukup besar dan terkadang pula mendapatkan pendapatan yang sedikit. Hal ini disebabkan karena adanya banyak faktor yang mempengaruhi. Menurut Salim dalam Indara (2017), ada beberapa faktor yang mempengaruhi pendapatan nelayan antara lain faktor modal dan biaya produksi, jumlah tenaga kerja, jarak tempuh melaut, dan lama melaut atau pengalaman. Selain faktor tersebut faktor teknologi seperti penggunaan mesin pada perahu (motorisasi), faktor sosial ekonomi dalam hal ini umur, tingkat pendidikan, pengalaman, tanggungan keluarga, musim dan faktor tata niaga dalam hal ini pemasaran hasil tangkapan nelayan merupakan faktor-faktor yang mempengaruhi pendapatan nelayan.

Berdasarkan uraian tersebut maka tujuan penelitian ini adalah untuk menganalisis faktor-faktor yang mempengaruhi pendapatan nelayan tangkap pancing Rawai di Kelurahan Sumpang Binagae di Kecamatan Barru

\section{METODE}

Jenis penelitian ini adalah deskriptif kuantitatif dengan pendekatan survey. Lokasi penelitian di kelurahan sumpang binangae Kecamatan Barru. Polulasi dalam penelitian ini sebanyak 46 orang kepala rumah tangga. Penelitian merupakan penelitian populasi. Teknik pengumpulan data yang digunakan yakni, observasi, wawacara dan dokumentasi. Teknik analisis data menggunakan analisis regresi linear berganda. 


\section{HASIL DAN PEMBAHASAN}

Untuk melihat kesejahteraan seorang nelayan tentu salah satunya dapat dilihat dari tingkat pendapatan yang diterimanya. Namum yang menjadi permasalahan adalah tidak menentunya pendapatan nelayan itu sendiri dibandingkan dengan usaha-usaha lainnya. Karena nelayan hanya bisa melaut ada saat kondisi cuaca sedang baik. Selain itu, adanya banyak factor yang bisa mempengaruhi pendapatan nelayan. Untuk mengetahui faktor apa saja yang berpengaruh terhadap pendapatan nelayan dapat dilihat pada tabel berikut ini:

Tabel 1. Hasil Analisis Faktor-faktor yang Mempengaruhi Pendapatan Nelayan Tangkap pancing Rawai Kelurahan Sumpang Binangae Kacamatan Barru

\begin{tabular}{|c|c|c|c|c|}
\hline \multirow{2}{*}{ Variabel Independen } & \multirow[t]{2}{*}{$\mathrm{TH}$} & \multicolumn{3}{|c|}{ Nelayan Pancing (Rawai) } \\
\hline & & $\mathrm{B}$ & t- hitung & Sign \\
\hline 1. Modal Kerja & + & $0.431 *$ & 2.496 & 0.017 \\
\hline 2. Alat Tangkap Pancing (rawai) tetap & + & $0.644 *$ & 2.667 & 0.011 \\
\hline 3. Lama melaut & + & $0.492 *$ & 2.275 & 0.029 \\
\hline 4. Pengalaman & + & $0.140^{*}$ & 2.094 & 0.047 \\
\hline 5. Tanggungan Keluarga & + & $0.068^{\mathrm{ns}}$ & 0.975 & 0.336 \\
\hline 6. Pendidikan & + & $0.019^{\mathrm{ns}}$ & 0.297 & 0.723 \\
\hline 7. Umur & & $0.082^{\mathrm{ns}}$ & 0.391 & 0.698 \\
\hline Konstanta & & & & 2.019 \\
\hline F Hitung & & & & 10.890 \\
\hline Sign $\mathrm{f}$ & & & & 0.000 \\
\hline $\mathrm{R}^{2}$ & & & & 0.727 \\
\hline Adjusted R Square & & & & 0.635 \\
\hline $\mathrm{N}$ & & & & 46 \\
\hline
\end{tabular}

Sumber : Analisis data setelah di Olah

Keterangan: TH : Tanda harapan

$$
\begin{aligned}
& * \quad \text { : Signifikan pada taraf Signifikansi 0,05 ( 5\%) } \\
& \text { ns : Tidak Signifikan }
\end{aligned}
$$

\section{1. $\mathbf{U j i} \mathbf{R}^{2}$ dan Adjusted $\mathbf{R}^{2}$}

Uji $\mathrm{R}^{2}$ digunakan untuk mengetahui seberapa jauh variasi independen dapat menerangkan dengan baik variabel dependen. Hasil analisis data, nilai $\mathrm{R}^{2}$ sebesar 0,727 ini berarti 72,7 persen variasi variabel tersebut dapat menerangkan dengan baik variabel pendapatan nelayan sedangkan sisanya 27.3 persen dipengaruhi oleh variabel lain diluar model sedangkan nilai Adjusted $\mathrm{R}^{2}$ di peroleh nilai 0.635 atau 63,5 persen

\section{Uji Secara Simultan (Uji F)}

Uji $F$ dilakukan untuk mengetahui apakah secara keseluruhan variabel bebas (independen) berpengaruh terhadap variabel dependen. Hasil analisis data, diperoleh nilai $\mathrm{F}$ hitung 10.890 dengan tingkat signifikansi 0.000 lebih kecil dari taraf signifikansi yang digunakan yakni 0,05. Maka dapat dikatakan bahwa semua variabel independen secara bersama-sama berpengaruh terhadap variabel dependen

\section{Modal Kerja Nelayana Tangkap Pancing Rawai \\ Modal kerja adalah biaya-biaya yang} harus dikeluarkan oleh nelayan untuk memperoleh hasil dari usahannya dan mendapatkan pendapatan. Hasil analisis data penelitian pada nelayan di Kelurahan Sumpang Binangae dimana modal kerja yang di keluarkan nelayana bepengaruh positif terhadap pendapatan nelayan pada tingkat signifkansi atau kesalahan 5 persen dimana Nilai t hitungnya yang diperoleh sebesar 2.496 diikuti nilai koefisien $\beta$ yang 
bernilai 0.431 dengan tingkat signifikasi 0,017 lebih kecil dari taraf signifikansi 0.05 . Hal ini telah sesuai dengan tanda yang di harapan pada tabel di atas yaitu tanda postif, dimana tanda positif berarti bertambahnya modal kerja yang di keluarkan nelayanan diharapkan juga dapat meningkatkan pendapatan nelayan.

\section{Jumlah Alat tangkap}

Hasil analisis data menunjukkan bahwa jumlah alat tangkap pancing (rawai) yang digunakan berpengaruh nyata secara positif terhadap pendapatan nelayan di Kelurahan Sumpang Binangae dimana nilai $\mathrm{t}$ hitungnya 2.667 dengan nilai koefisien $\beta$ yang bernilai positif 0,644 dengan tingkat signifikasi 0.011 lebih kecil dari taraf signifikansi yang digunakan 0.05. Hal ini telah sesuai dengan tanda yang diharapkan yakni tanda positif artinya bahwa apabila jenis alat tangkap pancing (rawai) meningkat (bertambah) maka pendapatan nelayan pancing rawai juga akan mengalami peningkatan. Jadi semakin banyak jumlah mata pancing yang digunakan maka akan semakin bertambah pula pendapatan yang bisa diperoleh nelayan. Pengaruh postif dari alat tangkap pancing (rawai) terhadap pendapatan nelayan disebabkan karena rata-rata nelayan di kelurahan sumpang binangae menggunakan 300 s.d 400 mata pancing yang tentunnya akan semakin besar pula peluang untuk mendapatkan hasil tangkap ikan yang lebih banyak. Pada wilayah penelitian, ikan hasil tangkapan nelayan pancing memiliki nilai ekonomi yang lebih tinggi seperti jenis ikan kakap merah, Sunu, kerapu dan lain-lain

\section{Lamanya melaut}

Berdasarakan hasil analisis data menunjukkan bahwa lama melaut untuk nelayan yang menggunakan alat tangkap pancing (rawai) setiap tripnya berpengaruh nyata secara positif terhadap pendapatan nelayan dimana nilai $t$ hitungnya 2.275 dengan nilai koefisien $\beta$ yang bernilai positif 0.492 dengan tingkat signifikasi
0.029 lebih kecil dari taraf signifikansi yang digunakan 0.05. Hal ini sesuai dengan tanda harapan yakni postif artinya jika nelayan melaut dalam waktu yang cukup lama, maka pendapatan hasil tangkapan akan meningkat yang tentu akan meningkatkan pendapatan nelayan. Lamanya melaut seorang nelayan dalam menangkap ikan setiap kali turun untuk mengakap ikan atau setiap tripnya (satu kali melaut) tentu akan mempengaruhi pendapatan yang bisa dia terima. Signifikannya lama melaut disebabkan karena nelayan pada lokasi penelitian, waktu melaut yang digunakan nelayan dalam menagkap ikan cukup lama sebagaimana hasil wawancara dan angket peneliti dimana nelayan rata-rata melaut antara 13 s.d 17 jam. Secara teori, semakin lama seorang nelayan melaut maka semakin besar pula kemungkinan untuk memperoleh tangkapan ikan yang lebih banyak dan tentunya akan meningkatkan pendapatan yang akan diterimahnya.

\section{Pengalaman Melaut}

Hasil penelitian variable pengalaman kerja nelayan tangkap rawai di Kelurahan Sumpang Binangae berpengaruh nyata secara postif dimana nilai $\mathrm{t}$ hitungnya 2.094 dengan nilai koefisien $\beta$ bernilai 0.140 dengan tingkat signifikasi 0.047 lebih kecil dari taraf signifikansi yang digunakan 0.05. Hal ini juga sesuai dengan tanda postif yang diharapkan, dimana semakin berpengalaman seorang nelayan, maka semakin besar kemungkinannya untuk dapat meningkatkan pendapatan yang akan diterimanya, karena nelayan yang berpengalaman tentu tahu cara mengatasi hambatan dalam setiap usahanya menangkap ikan. Faktor pengalaman merupakan salah satu faktor yang sangat penting yang mesti dimiliki oleh seorang nelayan. Nelayan yang memiliki atau mempunyai pengalaman yang lebih banyak dalam hal melaut tentu akan relatif lebih berhasil dalam penangkapan ikan dilaut. Pada lokasi penelitian sebagaimana hasil dari angket 
penelitian menunjukkan bahwa nelayan memiliki pengalaman yang cukup lama yakni antara 21 s.d 30 tahun sebanyak 43.48 persen atau sekitar 20 responden

\section{Tanggungan Keluarga}

Hasil analisis data bahwa jumlah tanggungan keluarga nelayan yang mengunakan alat tangkap pancing di Kelurahan Sumpang Binangae tidak berpengaruh nyata secara signifikan terhadap pendapatan nelayan dimana nilai t hitungnya 0.975 dengan nilai koefisien $\beta$ yang bernilai positif 0.068 dengan tingkat signifikasi 0.336 lebih besar dari taraf signifikansi yang digunakan 0.05 , artinya ada-tidaknya peningkatan atau pertambahan jumlah tanggungan nelayan tidak terlalu memberi dampak terhadap pendapatan nelayan pancing. Pada lokasi penelitian jumlah tanggungan keluarga responden yang paling rendah antara $1 \mathrm{s.d}$ 4 jiwa sebanyak 30 jiwa atau 65,22 persen pada lokasi penelitian dan jumlah tanggungan paling tinggi diatas 7 jiwa sebanyak 1 jiwa atau 2,17 persen.

\section{Pendidikan Nelayan}

Hasil analisis data penelitian pada variabel tingkat pendidikan nelayan yang menggunakan alat tangkap pancing terhadap pendapatan nelayan tidak berpengaruh nyata secara signifikan terhadap pendapatan nelayan dimana nilai t hitungnya 0.297 dengan nilai koefisien $\beta$ yang bernilai positif 0.019 dengan tingkat signifikasi 0.723 lebih besar dari taraf signifikansi yang digunakan 0.05

Pendidikan formal dapat dijadikan salah satu dasar untuk mengukur produktivitas seorang nelayan. Secara teori, semakin tinggi tingkat pendidikan yang dimiliki semakin tinggi pula produktivitas dan kemampuan mengelolah usaha tangkap dan berani mengambil risiko dalam setiap tindakan usahanya dalam memperoleh pendapatan. Tidak berpengaruhnya pendidikan terhadap pendapatan nelayan pada lokasi penelitian disebabkan karena sebagian besar tingkat pendidikan formal responden tidak tamat sekolah dasar (SD) atau sekolah rakyat (SR) yang cukup tinggi yakni 47.83 persen

\section{Umur}

Hasil penelitian variable Umur nelayan yang menggunakan alat tangkap pancing di Kelurahan Sumpang Binangae tidak berpengaruh signifikan dimana nilai t hitungnya 0.391 dengan nilai koefisien $\beta$ yang bernilai positif 0.082 dengan tingkat signifikasi 0.698 besar dari taraf signifikansi yang digunakan 0.05 . Hal ini tidak sesuai dengan tanda harapan yang negatif yaitu jika umur nelayan bertambah, maka pendapatan usaha nelayan yang menggunakan alat tangkap pancing akan menurun. Pada wilayah penelitian pengaruh positif dari umur nelayan disebabkan karena masih ada responden yang berumur di atas 60 tahun yang melakukan aktivitas penangkapan ikan atau masih mampu meningkatkan produktivitasnya hal ini bisa disebabkan karena nelayan tersebut memiliki pengetahuan serta memiliki keterampilan atau teknik penangkapan ikan pada saat melaut, serta masih kuatnya motivasi yang dimiliki guna untuk memenuhi kebutuhan keluarganya.

\section{KESIMPULAN DAN SARAN}

Berdasarkan hasil penelitian dan pembahasan, maka dapat disimpulkan bahwa besar-kecilnya pendapatan nelayan yang menggunakan alat tangkap pancing secara nyata dan signifikan dipengaruhi oleh variabel modal kerja, alat tangkap pancing, lama melaut dan pengalaman sedangkan variabel tanggungan keluarga, pendidikan dan umur tidak berpengaruh nyata secara signifikan terhadap pendapatan nelayan. pendapatan nelayan tangkap pancing rawai memiliki tingkat pendapatan yang cukup baik disebabkan jenis tangkapan ikannya memiliki nilai ekonomis atau harga jual yang lebih tinggi.

Adapun saran dalam penelitian ini adalah:

1. Peran pemerintah daerah dalam hal ini Dinas Perikanan dan Kelautan untuk 
bisa membantu dengan menyediakan atau memfasilitasi nelayan dalam hal permodalan guna meningkatkan kesejahterannya menjadi lebih baik.

2. Nelayan dalam melakukan aktvitas menangkap ikan harusnya tidak hanya menggunakan satu jenis atau satu macam alat tangkap saja. Tetapi perlu juga menggunakan alat tangkap lainnya agar dapat meningkatkan pendapatannya.

\section{UCAPAN TERIMAKASIH}

Dalam penyelesaian karya ini, penulis berterima kasih yang sebesar-besarnya kepada kepala kelurahan Sumpang Binangae yang telah memberikan izin dan membantu dalam proses pengumpulan data penelitian dan seluruh pihak yang telah membantu yang tak bisa saya sebutkan satu persatu.

\section{DAFTAR PUSTAKA}

Daniel, Moehar. 2002. Pengantar Ekonomi Pertanian. Jakarta: Bumi Aksara.

Evy, dkk. 2001. Usaha Perikanan di Indonesia. Jakarta: Mutiara Sumber Widya

Harahap, R.H., dan Subhihar. 2005. Orientasi Nilai Budaya Masyarakat Nelayan Melayu Pantai Timur Sumatera, Isu-isu Kelautan dari Kemiskinan hingga Bajak Laut. Yogjakarta: Pustaka Pelajar.

Hendratmoko dan Marsudi. 2010. Analisis

Tingkat Keberdayaan Sosial

Ekonomi Nelayan Tangkap di

Kabupaten Cilacap. Dinamika Sosial Ekonomi Volume 6 Nomor 1 Edisi Mei 2010 (diakses di internet Tanggal 19 Oktober 2019).

Indara, Sofyan R dkk. 2017. FaktorFaktor Yang Mempengaruhi Pendapatan Nelayan Tangkap Di
Desa Bongo Kecamatan Batudaa Pantai Kabupaten Gorontalo. AGRINESIA Vol. 2 No. 1 November 2017.

Lewa, Syahriani. 1997. Analisis Faktorfaktor yang Mempengaruhi Pendapatan Nelayan (Studi Kasus di Kabupaten Bone Sulawesi Selatan). Skripsi. IPB

Mudyahardjo. 2001. Pengantar Pendidikan Jakarta. Rajawali pers.

Masyhuri. 1996. Menyisir Pantai Utara. Yogyakarta: Yayasan pustaka Nusantara.

Mulyadi S. 2005. Ekonomi Kelautan. Jakarta: Raja Grafindo Persada.

Mujiani, L. Nagib, dan Z. Fatoni. 2007. Kondisi Sosial Ekonomi Masyarakat di Lokasi Coremap II Desa Mapur, Kecamatan Bintan Timur, Kabupaten Bintan (Perbatasan Negara Malaysia dan Singapura), CRITC-LIPI, Jakarta

Rahardja, Pratama. 2008. Pengantar Ilmu Ekonomi Mikro ekonomi \& Makroekonomi. Jakarta: LP FE UI.

Rahim, Abd. 2010 Analisis Harga Ikan Laut Segar Dan Pendapatan Usaha Tangkap Nelayan Di Sulawesi Selatan. Disertasi-S3 Fakultas Pascasarjana Universitas Gadjah Mada, Yogyakarta (tidak dipublikasikan)

Rahmat W. P. 2010. Faktor-faktor yang mempengaruhi pendapatan usaha tangkap nelayan tradisional di wilayah pesisir pantai Kelurahan Kalu-kalukuang Kecamatan Liukang Kalmas Kabupaten Pangkajene dan Kepulauan. Skripsi UNM (tidak dipublikasikan) 
Riptanti, E.W. 2005. Karakteristik dan Persoalan Ekonomi Masyarakat Petani dan Nelayan pada Kawasan Pantai di Torosiaje Kabupaten Pohuwatu, Caraka Tani. Jurnal Ilmu-ilmu Pertanian Vol.22 No.2 Oktober 2005. Surakarta: Universitas Sebelas Maret.

Salim, Agus. 2006. Analisis Tingkat Pendapatan Dan Factor-Faktor Yang Mempengaruhinya Di Kecamatan Syiah Kuala Kota Madya Banda Aceh. Tesis. USU

Yusuf, Muhammad. 2003. Analisis Faktor-Faktor yang Mempengaruhi Pendapatan Masyarakat Nelayan Di Kelurahan Tallo Kota Makassar. Tesis. PPs UNM tidak dipublikasikan

Wahyuningsi dkk. 1997. Budaya Kerja Nelayan Indonesia Di Jawah Tengah (Kasus Masyarakat Nelayan Desa Wonokerto Kulon Kecamatan Wiradesa Kabupaten Pekalongan). Jakarta: Departemen pendidikan \& Kebudayaan 